\title{
Reading (in) the Antipodes: New Zealand and Pacific Literatures in Spanish Translation
}

\author{
PALOMA FRESNO-CALLEJA
}

\begin{abstract}
This article considers the Spanish translations of New Zealand and Pacific authors and explores the circumstances that have determined their arrival into the Spanish market as well as the different editorial and marketing choices employed to present these works to a Spanish readership. It considers the scarcity of canonical authors, the branding of Maori and other "ethnic" voices, the influence of film adaptations and literary prizes in the translation market, and the construction of the "New Zealand exotic" in works written by non-New Zealand authors which, in the absence of more translations from Spain's literary Antipodes, have dominated the Spanish market in recent years.
\end{abstract}

\section{Introduction}

In October 2012, New Zealand was chosen as guest of honour at the Frankfurt Book Fair, the world's largest and most prominent event of this type. The motto of the New Zealand delegation was: "He moemoea he ohorere / While you were sleeping," an ingenious allusion to the geographical distance between Europe and its Antipodes, but also a reminder of the country's literary potential, which Europeans were invited to wake up to. The choice of New Zealand as a guest of honour reflected the enormous interest of German readers for its literature and culture, summarized in Norman Franke's remark that "Germans are crazy about all things Kiwi." As Franke points out, more New Zealand books have been translated into German than into any other European language, and the impact of the fair resulted in an immediate increase of sales and a thirst for new titles. ${ }^{2}$ Spanish newspapers reported the event with curiosity but on a slightly skeptical note. La Vanguardia defined New Zealand as "un peso pluma" ["featherweight"] and its writing as "la literatura del fin del mundo" ["The literature from the end of the world"]. ${ }^{3}$ El País remarked on the healthy reading habits of New Zealanders, but described the country as an "invitado insólito" [unusual guest] ${ }^{4}$ because of its isolation as well as the small size of its publishing industry. In both cases the focus was placed on the notion of New Zealand as a remote and culturally insignificant nation, in contrast with remarks made in relation to countries like Iceland or Finland, chosen as guest of honour in 2011 and 2014 respectively, whose writing was defined in significantly different terms. ${ }^{5}$

As becomes evident from the scarcity of New Zealand and Pacific titles available in their language, ${ }^{6}$ Spanish readers have not yet woken up to the diverse literary production of the region. Although it is difficult to establish neat conclusions about the loosely connected selection of works I will mention below, I explore the literary or commercial reasons behind the decision to publish certain New Zealand authors and the specific cultural and marketing codes through which their works have been presented to a non-academic readership. As discussed below, the translation of particular works may occasionally reflect their specific literary qualities or the impact in their local publication context, but quite often responds to what Ponzanesi defines as "the Economy of prestige," where prestige derives not only from "old Western paradigms of literariness and craftsmanship but also ... [from] new, more evasive cultural concepts ranging from cosmopolitanism to authenticity and ethnic-chic," 7 as determined by specific commercial or social trends, or non-literary aspects. The title of my article thus makes reference to the set of translated works through which Spanish people read their literary Antipodes while referring at the same time to the ways in which this specific 
selection of works reveals a process of reading in New Zealand's Antipodes that is clearly determined by global publishing trends rather than by the specificities of the Spanish market or the taste of Spanish readers.

My general contention is that New Zealand literature is not being marketed in Spain as a compact or unitary body of works, as the Frankfurt Book Fair appears to suggest; that is, the national or postcolonial label favoured in academic approaches or specialized accounts of New Zealand literature is hardly ever conjured up as a defining feature of the works in question. These translated works actually come to integrate a loosely defined canon of "world literature" available to Spanish readers from a range of different locations, a label which Damrosch applies to "all literary works that circulate beyond their culture of origin [and that are] actively present within a literary system beyond that of ... [their] original culture." ${ }^{8}$ My analysis thus departs from Damrosch's understanding of world literature "not [as] an infinite, ungraspable canon of works but rather [as] a mode of circulation and of reading, a mode that is as applicable to individual works as to bodies of material, available for reading established classics and new discoveries alike." "The selection of New Zealand and Pacific works translated into Spanish I mention below become part of a loosely defined canon of world writing where their specific "New Zealandness" becomes secondary to other defining features that seem to have determined their eligibility to be translated and the ways in which they are labelled and presented to readers in Spain.

\section{Translating the New Zealand Canon?}

If one were to form a more comprehensive overview of the formative years and subsequent development of New Zealand literature based on what is available in Spanish, the list would be exclusively limited to the country's most iconic literary figures: Katherine Mansfield and Janet Frame. Katherine Mansfield is the only author whose whole literary production is translated into Spanish, a reflection of her international status and, most specifically, of the influence of her work in continental Europe as seen in recent critical studies. ${ }^{10}$ Although these works do not mention the reception of her works in Spain, her most relevant short story collections had already been translated by the 1940s and her fiction, as well as her diary and letters, have continued to be re-edited since then. Focusing on the particularities of this relatively large number of academic and popular editions of her work would exceed the length of this article; but, generally, editorial choices have tended to echo traditional critical approaches to Mansfield coming from the Anglophone world as well as the reception of her work in other European countries, occasionally incorporating more elaborate critical responses.

Such is the case of recent interpretations of Mansfield's status as a (post)colonial author, ${ }^{11}$ "a white settler writer with contradictory allegiances and affiliations," ${ }^{12}$ struggling to redefine her connections with her homeland from her position as an exiled colonial. This approach informs, for instance, El aloe, the 2012 translation of The Aloe (1930), published in the collection "Bárbaros." 13 The publisher's summary starts by emphasizing the postcolonial dimension of the story: "La novela describe una situación parcialmente autobiográfica y el desasosiego de Mansfield por su pertenencia a la casta de los invasores" ["The novel is partly autobiographical and describes Mansfield's restlessness as a result of her belonging to the caste of invaders"], pointing to Mansfield's contradictory position. Yet the summary concludes invoking potentially more appealing aspects of Mansfield's biography: "Una de sus primeras amantes fue, de hecho, la maorí Maata Mahupuku." ["One of her first lovers was, in fact, the Maori girl Maata Mahupuku."] ${ }^{14}$ This is in line with more traditional "feminist, generic, biographical and social or historical" 15 approaches which continue to mediate the marketing of her work for a non-academic readership. ${ }^{16}$ 
An example of this emphasis on the more turbulent aspects of Mansfield's life is seen in the author's profile offered by Alba, which released independent editions of At the Bay (En la bahía) and In a German Pension (En un balenario alemán) ${ }^{17}$ in 2001:

Katherine Mansfield nació en Wellington, Nueva Zelanda, en 1888. En 1909 se casó con un cantante al que abandonaría la misma noche de bodas. Embarazada, fue desheredada por su madre. Después de abortar tuvo una aventura con un traductor polaco que la chantajearía. Es entonces cuando publicó En un balneario alemán y cuando conoció al crítico literario John Middleton Murry, su principal relación. Es autora de Fiesta en el jardín y otros cuentos, entre otras. Murió en 1923 a los 34 años, enferma de tuberculosis. ${ }^{18}$

[Katherine Mansfield was born in Wellington, New Zealand, in 1888. In 1909 she married a singer who abandoned her on their wedding night. Pregnant, she was disowned by her mother. After suffering a miscarriage, she had an adventure with a Polish translator who would later on blackmail her. She published In a German Pension at the time she met the literary critic John Middleton Murry, her long-life partner. She is the author of The Garden Party and Other Stories, among others. She died of tuberculosis in 1923 at the age of 34].

The interest in the biographical is also evident in the diverse translations and re-editions of Mansfield's letters and diaries appearing from the late seventies, ${ }^{19}$ as well as the preference for the translation of biographies of Mansfield written by Claire Tomalin-Katherine Mansfield: A Secret Life $(1987)^{20}$ —or Pietro Citati ${ }^{21}$ — translated from the French and described by Kimber as "hagiographical in tone and content"- ${ }^{22}$ over more academic accounts of her life which are not yet available in Spanish.

A similar biographical emphasis can be traced in the selection and presentation of the works by Janet Frame. Despite Frame's iconic status, it is surprising that only three of her novels have been translated into Spanish. Frame's second novel Faces in the Water (1961) appeared as Rostros en el agua (1965) ${ }^{23}$ and her third work, The Edge of the Alphabet (1962), was published as El margen del alfabeto (1966), ${ }^{24}$ coinciding with the publication of her works in several countries while Frame was living in London. ${ }^{25}$ Yet, three decades would pass before her work would be translated again into Spanish, with a new translation of Faces in the WaterRostros en el agua (1991) 26 - her three-volume autobiography An Angel at My Table-Un ángel en mi mesa (1991) ${ }^{27}$ —and her children's book Mona Minim and the Smell of the Sun (1969), which appeared as Mona Minim y el olor del sol (1994). ${ }^{28}$

To understand this particular chronology, one needs to consider the editorial projection given to Frame's works from the late 1980s and the internationalization of her figure, evident in the reception of numerous awards and recognitions, including her nomination for the Nobel Prize of literature. Related to this was the "creation" of her fictional self after the release of $A n$ Angel at My Table, Janet Campion's 1990 film adaptation of her autobiography. While the Spanish translation of Frame's autobiography clearly capitalized on the worldwide success of the movie, implicitly drawing the Spanish readers' attention to the fact that she spent some months in Ibiza, the re-edition of Faces in the Water can be explained as a result of a prioritization of those works which appeared to be autobiographical. Faces in the Water describes Istina Mavet's stay in diverse psychiatric institutions, and was inspired by the author's experience in different mental hospitals as a young woman after she received a wrong diagnosis of schizophrenia and was subjected to electric shock treatment. These coincidences have made critics read the novel as merely autobiographical, despite Frame's insistence that she was fictionalizing experiences she went through in an attempt to "build a more credible 'mad' central character [and] planning a subdued rather than a sensational record." 29 
A similar interest in the autobiographical dimension of Frame's works can explain the translation of her novel, Towards another Summer, originally written in 1963 and published posthumously in 2008. Hacia otro verano ${ }^{30}$ appeared in 2009 , coinciding with the re-edition of her autobiography by the same publishers. The back cover stresses the autobiographical and the potentially controversial nature of the story, explaining that Frame considered this novel: "demasiado personal para ser publicada en vida, pero siempre se aseguró de que no se perdiera." ["Too personal to be published during her lifetime, but she always made sure the novel was not lost"].

Both Mansfield and Frame are thus presented as unique in their way of writing, their innovative narrative techniques and their reflection of states of mind, and singled out as key names in the development of a specifically female literary tradition, but not necessarily as representatives of a specific New Zealand sensibility or foundational for a specific New Zealand canon. To the general public they tend to be translated as unconventional, troubled, unique or eccentric personalities and the more or less explicit references to their lives in the paratextual and promotional material clearly connects their work with their biographies, with pictures of the authors often used to illustrate not only their diary or auto/biographies but their fiction. Recent non-academic editions also show a preference for the marketing of their lives and experiences in Europe as a way to connect with (female) Spanish readers, in a way that minimizes their status as canonical New Zealand authors and integrates them into a less narrowly defined canon of world literature by female writers of various origins.

\section{Lost in Translation: Maori Voices}

The same scarcity of translated canonical or well-established Pakeha voices affects Maori writing. To date, Spanish readers can only access Maori literature through three novels: Patricia Grace's Potiki (1986), published in 1999 by Txalaparta; ${ }^{31}$ Alan Duff's Once Were Warriors (1990), translated in 1999 as Guerreros de antaño; ${ }^{32}$ and Witi Ihimaera's The Whale Rider (1987) which came out in 2004 as La leyenda de las ballenas. ${ }^{33}$ This reduced list proves that Spain is clearly the exception to Haag's conclusion that the translation of New Zealand's indigenous authors has become "a persistent phenomenon" 34 in Europe. As seen in his statistical study, only 5 percent of those translations are in Spanish, versus 32 percent in German or 15 percent in French. ${ }^{35}$ Although Grace, Duff and Ihimaera are three of the most relevant contemporary Maori writers and their works illustrate contrasting approaches to Maori identity, in Spain Maori culture continues to be associated with stereotypical images of tattooed Maori warriors and haka dancers. These translations provide much needed windows into the complexities of New Zealand's indigenous culture, but they are clearly insufficient to reflect the variety and relevance of Maori writing and fail to offer a consistent approach to their culture and their role in the expansion of monocultural definitions of New Zealand literature.

The evidence suggests that literary awards, previous translations into other European languages and, most importantly, the filmic versions of two of these novels were essential to establish the visual and commercial foundations for the subsequent importation of these novels into Spain. The Spanish translation of Potiki, for instance, is presented as "el más premiado y traducido trabajo de cuantos ha publicado esta escritora maori" ["the most awarded and translated work by this Maori writer"] with references to the Finnish (1990), German (1993), French (1993) and Dutch (1994) translations on the dust jacket. This positions the Spanish edition within the European genealogy of translations, endorsing its presence in our market. On the other hand, the inclusion of Potiki in the collection "Gebara"-formed by an heterogeneous body of fiction and non-fiction by authors as diverse as Jamaica Kincaid, Ngugi Wa Thiong'o, Franz Fanon, Nelson Mandela, Fidel Castro or Che Guevara-highlights the political dimension of a novel which narrates the struggles of a coastal Maori community to preserve their land and culture from a group of land developers. Although the back cover 
stresses the novel's poetic qualities, the clumsy and unpolished translation manages to completely spoil Grace's unique style. Likewise, the original cover-which reproduces the carved figure of the Potiki so central to the story-is relegated to a small black and white image inside the novel, and substituted by a photograph of a group of Maori people, with the aim of highlighting the more ethnographic or sociological dimension of the text. Significantly, this edition also includes a glossary with explanations of Maori concepts and expressions, which does not appear in the original novel, in an attempt to facilitate the foreign audience's entry into the text's numerous mythological allusions and Maori concepts. In the absence of more skillful translations of Grace's works, the Spanish edition of Potiki thus fails to reflect the quality and influence of the original novel, loosely defining it within the broader category of the indigenous or the political that forms the collection.

If the political perspective seems to dominate the packaging of Grace's novel, Duff's and Ihimaera's texts are clearly conditioned by the filmic. Duff's controversial vision of Maori urban life attracted a great deal of attention, as well as negative criticism from Maori and Pakeha alike, but the novel was nevertheless widely read and acclaimed. Evidence of this success is the fact that abroad it has often been considered as "the most widely recognized New Zealand book title." ${ }^{36}$ The international recognition was reflected in its translation into several European languages, although as seen in Haag's bibliographic compilation, ${ }^{37}$ most of these translations only came up after the 1994 film adaptation by Lee Tamahori. The Spanish edition clearly draws on the film's appeal and worldwide success, as evident in the explicit reference to Tamahori in the back cover, and the inclusion of a black and white booklet of photographs from the movie. By placing these iconic images within the novel, the publishers channel the readers' potential responses to the text through the specific visual input provided by the film and the director's personal intervention into the original text.

This is also the case with the successful filmic adaptation of Witi Ihimaera's The Whale Rider (1987). The novel did not attract a great deal of attention when it was originally published, yet Niki Caro's 2002 film adaptation, Whale Rider, granted it a second life. The film's growing popularity derived from the numerous awards it received in several festivals, and in particular from Keisha Castle-Hughes' Oscar Nomination as Leading Female Actress. Its success prompted the publication of a commemorative New Zealand edition as well as an international-and slightly rewritten-version of the novel (2003). ${ }^{38}$ Evans, who has explained these linguistic changes in the light of Huggan's notion of the "Postcolonial Exotic," 39 has argued that these alterations reduce the local specificities of the novel, processing "its "New Zealandness' and 'Maoriness' ... for a northern-hemisphere market." ${ }^{40}$ The Spanish translation, which reproduces the film's poster in its cover, is based on this international edition, which reduces the number of Maori words and the length of the original glossary for the sake of foreign readers, simplifying the contents and allusions of the original novel. Interestingly, although the publishers' website presents the novel as a story for readers of all ages,${ }^{41}$ it was marketed under the category of young adult fiction, thus minimizing its political contents, and stressing the mythological and fantastic quality of the plot, the reversal of what happened with Grace's novel.

Although the scarcity of Maori works available in Spanish demonstrates that Spain is behind other European countries in the number and frequency of translations, the choice of the aforementioned works seems to have been determined by similar factors to those conditioning translations into other European languages: "funding policies, the production of films, the awarding of literary prizes and European literary festivals, as well as the nexus between publishing policies, broader international events and the increasing visibility of Indigenous peoples in European media." ${ }^{42}$ At the same time, the translations of these works into Spanish seem to respond more to a general interest for indigenous literatures worldwide than to a specific interest in Maori writing or culture in particular. This may explain why there has been 
no consistent attempt to expand the number of translations by other Maori authors, and why other works by Duff, Ihimaera and Grace remain unknown to Spanish readers.

\section{Branding the Exotic: Pacific and Asian Authors}

Any survey of contemporary New Zealand literature would not be complete if it omitted a reference to authors of diverse Pacific and Asian origins currently contributing to the expansion of the country's national narratives. It is, however, almost impossible for Spanish readers to reach any such conclusion, due to the virtual absence of translations. In her article on Francophone Pacific writing, Jean Anderson quotes the words of editor Robyn Bargh during the Frankfurt Book Fair that the Pacific is seen in Europe "as one large hole on the other side of the world, about which readers know very little." 43 Unless based in Australia, New Zealand or the United States, these authors are only published in small print-runs and by local presses, ${ }^{44}$ which constitutes a further problem in the distribution of their works outside the Anglophone market. Limitations exist even when these authors are widely read, as in the case of Albert Wendt. Born in Samoa and living in New Zealand, Wendt is considered the father of Pacific literature but, apart from two of his short stories, ${ }^{45}$ the rest of his vast production remains untranslated.

The only works of Pacific literature translated into Spanish are those by Samoan novelist and performance poet Sia Figiel. Her first novel, Where We Once Belonged (1996), which narrates the lives of a group of adolescent Samoan girls in response to ingrained colonial accounts of the Pacific, was awarded the 1997 Asia-Pacific Commonwealth Writers Prize for Best First Book, with Figiel being presented internationally as the "First Samoan female novelist." Figiel held a writing residency in Barcelona in 1999, invited by the Institució de les Lletres Catalanes. This visit coincided with the publication of her first novel in both Catalan (L'Indret d'on venim) $)^{46}$ and Spanish (El lugar donde nacimos) ${ }^{47}$ Her novella, The Girl in the Moon Circle (1996), was also published in 2001 as La muchacha en el círculo de la luna. ${ }^{48}$

The translations of Figiel's works have arguably contributed to reducing the gap between Spanish readers and Pacific literature, with reviewers accurately emphasizing Figiel's fierce

critique of both western views of the exotic Pacific and Samoa's restrictive moral rules. ${ }^{49}$ Yet Figiel remains the only representative of such a vast region, which may result in the market and symbolic value of her works overtaking their literary value as "the author comes to represent a whole nation." ${ }^{50}$ The process that separates the inscription of one's distinctive voice and the appropriation of that voice by the market is defined by Filipino-Australian writer Merlinda Bobis as the "Voice-Niche-Brand" framework ${ }^{51}$ to explain that the choice of one particular author may not only reflect the recognition of the work's literary qualities, but also the increasing demand of the Spanish market for young female ethnic or diasporic voices, with Figiel being allocated her own particular niche as the "first Samoan novelist." 52 The translation of Figiel's work does not seem to have opened the path for Spanish translations of other Pacific authors; it has rather served to fill in a specific cultural niche, as her novels enlarge the canon of ethnic female voices coming from different parts of the world and feeding western readers' taste for the exotic.

A similar argument could be employed in relation to Alison Wong's As the Earth Turns Silver (2009), published in Spanish as Cuando la tierra se vuelve de plata (2011) ${ }^{53}$ This is Alison Wong's first novel and the first by a New Zealander of Chinese descent, and narrates a love affair between a Pakeha widow and a Chinese shopkeeper and the racism and violence generated as a result of their relationship. Wong has talked about the limitations imposed on "ethnic writers" and the local expectations that existed prior to the publication of her novel, as if she was to become "some kind of spokesperson for the New Zealand Chinese." 54 The fact that the novel was published by Penguin NZ evidently facilitated the visibility and projection of the title internationally, but, in my view, its marketability also derives from the fact that it 
can be simultaneously presented as the "first of its kind" (the first Chinese-New Zealand novel), and "one of many," that is, another novel about the Chinese diaspora. Wong's novel thus appears as "doubly exotic," because of its New Zealand setting as well as its Chinese material.

The Spanish publisher's choice of Wong's and Figiel's novels is thus a safe bet, both because of their uniqueness, but also due to the perceived similarities with previous titles that form part of the canon of world literature by diasporic or ethnic female voices already popular among Spanish readers.

\section{Global Voices from New Zealand}

Whereas the previous sections reflect how translations of New Zealand and Pacific authors are determined by the growing demand for "indigenous" or "ethnic" stories, in this section I mention the works of several writers who have been translated into Spanish, and whose works have not been placed under those categories. These include: Elizabeth Knox's The Vintner's Luck (1999) - La suerte del viticultor (2001) ${ }^{55}$; Kirsty Gunn's Rain (1994), The Keepsake (1997), This Place you Return to is Home (1999) and Featherstone (2002)_Lluvia (1997), El recuerdo (1999), Has vuelto a casa (2000), Featherstone $(2005)^{56}$; Eleanor Catton's The Rehearsal (2008) - El ensayo general (2013) ${ }^{57}$; and Kate de Goldi's young adult novel The 10pm Question (2009) — La pregunta de las 10 de la noche (2011). ${ }^{58}$ All these works are either set outside New Zealand, have an implicit but not fully distinctive New Zealand setting, or are written by authors established elsewhere, who might not always be explicitly defined as "New Zealand writers". In many cases, the author's country of origin is simply mentioned, but it remains insignificant in the specific marketing of the work.

The discussion about the flexible and changing limits of New Zealand literature has been the subject of recent criticism, given the increasing projection of some New Zealand writers in the global Anglophone market. Patrick Evans, for instance, takes a new generation of writers to task for falling prey to the power of international publishing forces whereby they "efface the localized referent" in favour of "a literature that can be found almost anywhere and everywhere." ${ }^{59}$ His views that New Zealand literature has moved "beyond its postcolonial moment into the global" 60 and that this has worked to the detriment of a specific national project, however, have been contested elsewhere. Erin Mercer discusses the works of writers like Paula Morris or Lloyd Jones, who have set their novels outside New Zealand, or authors like Eleanor Catton or Toa Fraser, who have chosen to write about New Zealand identity in a performative rather than essentialist mode, to account for the key markers of contemporary New Zealand identity: "The increasingly diverse composition of New Zealand society, a growing sense of independence from the colonial past and the quest for advantage in the globalized market."61

Likewise, writing about the international reception of Janet Frame's The Carpanthians (1988) and Elizabeth Knox's The Vintner's Luck (1999), Janet Wilson argues that the national paradigm which seemed to guide the formative years of New Zealand literature in the 1930s and 1940s has given way to new literary articulations which reflect the "reconfigured matrix of the global and the local." 62 Wilson reads both novels as revealing "the dilution of national concerns and new emphasis on the local which globalization enforces." 63 The fact that Knox places her characters in the French region of Burgundy, Wilson suggests, allows her to further her reflection of local identity while conferring a more mythical dimension to a story that not only resonates with her compatriots but with a more international audience, evident in its translation into several European languages. Evans himself praises recent novels by authors like Damien Wilkins that, despite being set elsewhere, manage to "place' New Zealand in contemporary time and space ... in the contemporary world [, showing] New Zealanders simply as human beings who are aware of their origins, that national identity is important and determining ... but not absolute." 64 
Has the apparent "Non-New Zealandness" of these works then facilitated their adaptability to the global translation market and their inclusion into the canon of world literature available in Spanish? Kirsty Gunn, who started her publishing career in England because New Zealand "editors [were] only interested in New Zealand stories," 65 explains in a 2008 lecture the influence that Mansfield has exerted in her work, in particular when it comes to her construction of place, which she defines as "placelessness." 66 In Spanish reviews, her work has not been particularly signposted as coming from a specific Antipodean location, but as an exploration of more general preoccupations. ${ }^{67}$ Although some of her works are, in fact, set in her home country, and Gunn is traditionally recognized as a New Zealand writer, she has continued to problematize reductive national labels:

Born in New Zealand, living in London, Scotland very much home... but so are other places... I was introduced once at a festival in New Zealand as having a liminal status. [T] he artist needs to be unhoused, un-homed, needs to exist in this other place that allows one to constantly create a home in the work. ${ }^{68}$

Kate de Goldi has offered similar arguments against the reductive use of the national label in the context of the 2012 Frankfurt Book Fair. Expressing her concerns about the display and presentation of New Zealand literature as a collective project, De Goldi argues that "in front of the blank page a national literature is usually the last thing on one's mind [as] one's writing life and imaginative urges are at times only loosely connected to the grand cultural narrative." ${ }^{69}$ De Goldi frames this debate in relation to the work of Margaret Mahy, the acclaimed New Zealand children's writer. She argues that although Mahy often sets her stories in a "recognizable, often prov ncial, New Zealand [she] is also a writer whose work is in so many respects ardently un-New Zealand-or at least ardently not the New Zealand we have, over time, assumed is the proper subject and setting for our fiction"; ${ }^{70}$ de Goldi calls this place "storyland."

In the Spanish editions of her work, Mahy's background as a New Zealander is only vaguely or erratically mentioned in the back cover biographies. ${ }^{71}$ Similarly to Gunn, Mahy recalls how at the start of her writing career New Zealand publishers would reject her books for not containing enough local material, ${ }^{72}$ whereas they were successful internationally because they were "imbued with British tradition." 73 Mahy and de Goldi, and other writers for children and for young adult readers, like Joy Cowley, whose works have also been translated, ${ }^{74}$ are writing for very specific audiences and in formats which may be easier to translate and export regardless of the amount of "New Zealand material" they contain. In these last cases, there might be a generic component ${ }^{75}$ which has made these books easily exportable as "children's fiction" rather than be chosen to illustrate New Zealand culture specifically.

The existence of translations of these "un-New Zealand" stories, to use de Goldi's term, ${ }^{76}$ might actually show that these writers are taking New Zealand to the world in ways that may appear to conform to global tastes, but can simultaneously work to resist the commodification of "New Zealand literature" as an apparently coherent body of works dealing with similar "post-colonial" preoccupations. This contradiction has been widely discussed by Sandra Ponzanesi who reflects on the "double-edged"77 nature of the post-colonial cultural industry and on the capacity of these products to both reflect complicity and exert a resistance against these neo-colonial and globalizing forces. ${ }^{78}$

\section{New Zealand "Booker Authors"}

One of the most evident ways to facilitate the translation of a specific work is its prize record prior to its arrival into the foreign language market, as well as its adaptability into media formats, like film or television. ${ }^{79}$ In this section I consider the extent to which the prestigious Man Booker Prize has had a direct impact on the translation and visibility of New Zealand 
authors in Spain. To date, New Zealand Booker winners include Keri Hulme's the bone people (1985), which has not yet been translated into Spanish, and Eleanor Catton's 2013 winner The Luminaries, a historical novel set during the gold rush period in New Zealand's South Island, published in December 2014 as Las luminarias. ${ }^{80}$

Sarah Shieff has traced the critical reception of the bone people concluding that "those from non-English speaking backgrounds find themselves disconcerted by the book's linguistic and structural idiosyncrasies." 81 The length, as well as the linguistic and the structural complexity of the novel may be an explanation for the absence of a Spanish translation, although translations in other European languages did appear from the late 1980s. ${ }^{82}$ In her study of the Prize, Squires illustrates the extent to which the Booker has gradually managed to balance the tensions between literary quality and popularity, by promoting quality works that may also become accessible (2007), and mentions the controversy over the bone people, which "in Booker mythology [stands] for a type of difficult, non-commercial literature that is an aberration from the more typically successful blend of the cultural and the commercial chosen by the judges and celebrated by the book trade." ${ }^{83}$ Although in origin the novel "was not a real candidate for the international marketplace," 84 the Booker has subsequently established it "as the Maori entrance into the world literature canon," ${ }^{85}$ in agreement with the growing commercialization of the prize ${ }^{86}$ My interpretation of Hulme's exclusion from the "translated canon" has more to do with the status of the prize in Spain at the time, than with the particularities of the novel or the process of canonization which may have occurred elsewhere. A quick search in national newspapers reveals that the familiarity of the Spanish press with the Booker and the interest in showcasing their winners is a fairly recent phenomenon, with no references to Hulme at the time of the concession of the award, although her name is often mentioned in news about the recent winner, Eleanor Catton. ${ }^{87}$

The invisibility of the first New Zealand Booker in the Spanish context contrasts with the immediate availability of Catton's novel. Even before being published, the novel attracted a fair deal of attention, with the publisher's website clearly branding Catton's text as "Novela ganadora del Man Booker Prize 2013" [Winner of the Man Booker Prize 2013], and several reviewers emphasizing Catton's status as the youngest author to have won the Booker ${ }^{88}$ This increasing visibility is also evident in relation to authors who made it into the short lists, like Lloyd Jones, whose Mr. Pip, shortlisted in 2007, appeared both in Spanish (El señor Pip) ${ }^{89}$ and Catalan (El senyor Pip) ${ }^{90}$ only a year later. The back cover highlights the credentials of the book in its local market: "Con la publicación de El señor Pip, Lloyd Jones se convirtió en uno de los escritores más célebres de Nueva Zelanda, y merced al boca oreja, el libro se encumbró hasta el primer lugar de las listas de éxitos de su país y Australia" ["With the publication of Mr. Pip, Lloyd Jones became one of the most popular New Zealand writers, and by word of mouth, the novel became a best-selling title in its country and Australia"]. The novel is thus promoted as both popular with readers and critics, reinforcing the balance suggested by Squires in the evolution of the award. The novels published by Jones before and after making it to the Booker short list, however, remain untranslated, thus revealing the interest in Jones primarily as a "Booker author" rather than a New Zealand writer. The same can be argued for Catton who is mostly presented as a Canadian-born writer, raised in New Zealand, where the novel is set, with no explicit reference to how her work reads in the context of a specific New Zealand tradition. The Luminaries is branded a Booker winner and Eleanor Catton, like Lloyd Jones, marketed primarily as a Booker author. The availability of their novels in translation, in any case, has not resulted in a chain reaction prompting the translation of other works by their compatriots. 


\section{The New Zealand Exotic in the Global Market}

In the absence of more translations of New Zealand authors and judging by the moderate impact of most of the aforementioned works, Spanish readers have relied almost exclusively on fictional recreations of New Zealand made by European authors. I started this essay by referring to the German fondness for New Zealand literature; this section deals with Sarah Lark, a German author based in Spain, who has become one of the greatest literary phenomena in recent years with her best-selling "New Zealand trilogies," the ultimate exponent of what I call—adapting Graham Huggan's formulation-the "New Zealand exotic". ${ }^{91}$ Lark's novels constitute a paradoxical exception to what I have argued above, as the marketing process has been based precisely on the successful presentation of their distinctive "New Zealand" features.

Lark first struck gold in Germany, where she has already published three trilogies set in New Zealand. In 2011 the first of these novels, En el país de la nube blanca (originally published in 2007 as Im Land der weißen Wolke) became a roaring success in Spain, followed in 2012 by La canción de los maoríes (Das Lied der Maori, 2008) and El grito de la tierra (Der Ruf des Kiwis, 2009), ${ }^{92}$ a family saga which starts with the two female protagonists migrating to New Zealand in the 1850s and concludes with their descendants' journey back to England prior to the First World War. ${ }^{93}$

Sarah Lark is the "New Zealand pseudonym" of Christiane Gohl who has also written fiction and non-fiction under different pen names: "tengo nombres distintos para cada editorial y cada género" ["I have different names for each publisher and each genre"]. ${ }^{94}$ Lark's profile on the publishers' website presents her as a global phenomenon, followed by millions of readers, and responsible for the consolidation of a genre of her own: the "landscape novel," whose formula includes resolute heroines, adventures, romance, history and exotic locations intended mostly for a female readership. ${ }^{95}$ Lark has explained how such formula was concocted when she was approached by her German publishers to revitalize the "landscape genre" and came up with the idea of setting her stories in New Zealand, a place she knew after having worked there as a tourist guide: "En ese momento El señor de los anillos acababa de salir y era muy famoso en Alemania. Todo el mundo quería ir a Nueva Zelanda. Yo conocía el país un poco y pensaba que podría ser un protagonista perfecto para mi novela." ["At the time Lord of the Rings had just come out and it was very popular in Germany. Everyone wanted to visit New Zealand. I knew the country a little bit and thought that it would be a great protagonist for my novel." "] ${ }^{96}$ The reference to the Lord of the Rings saga, crucial for the establishment of New Zealand as a filmic and tourist location throughout Europe, highlights the capitalization of a collective filmic imagery which is also exploited in the book covers, which present lonely female figures contemplating a sublime and empty landscape, blatantly invoking the gothic aesthetics of Jane Campion's The Piano, as noticed by multiple reviewers. ${ }^{97}$ What the successful marketing of Lark's novel demonstrates is that the literary industry now "has shifted its focus from supplying potential audiences to planning them, ... commissioning subjects, topics and areas to reach a major goal: to create a demand for the product, a real thirst for consumption prior to production." 98

The definition of these novels as "landscape novels" is accurate inasmuch as New Zealand is constructed as a painted scene on which the story occurs. The novels have also been classified as historical fiction or romance. A more accurate term I would propose to reflect the guided tour on which Lark embarks the readers could be that of "travel guide novel." Lark delves on descriptions of the land and facts about New Zealand's flora and fauna, stereotypical descriptions of Maori culture, and historical data which create very much the impression that we are going through the background information included in tourist guides. This information is often clumsily introduced into the story to provide authenticity, although the commonplace romantic or adventure elements could easily be removed and relocated elsewhere. ${ }^{99}$ 
The marketing of Lark's works has been remarkably well-planned, with Lark often featuring as "author of the month" in bookshops, her work displayed in prominent positions in shop windows, and a careful timing for the release of the many re-editions of each volume in diverse formats. To provide her readers with a fully authentic incursion into the exotic, one of the many re-editions of El grito de la tierra was also accompanied by a cookery booklet, $L a$ cocina neozelandesa, written by Lark herself, which contained "exóticas recetas de la cocina maori'" [exotic Maori recipes]. This type of armchair culinary tourism, targeting specifically a female audience, offers the ultimate incursion into the "Land of the Long White Cloud" by a European writer writing for a European readership. The trilogy thus works as evidence of what we might call the "the neo-colonial" or more specifically "The New Zealand exotic," whereby foreign authors monopolize the literary construction of a certain country reinforcing stereotypical descriptions of the land, its culture and peoples for the sake of romance, adventure or escapism. ${ }^{100}$ The result is that Lark's works construct a neatly defined New Zealand culture with "bankable, exotic elements recognizable to a [foreign] audience." ${ }^{101} \mathrm{New}$ Zealand landscape, native culture or icons are thus turned into a commodity, easily adaptable to a global formula which has proved successful in the hands of other authors setting their landscape novels in similarly "exotic" locations.

\section{Conclusions}

In the previous pages, I have attempted to highlight some of the cultural and commercial codes that have influenced the translation of New Zealand and Pacific authors into Spanish and the ways in which such selection of works may have mediated Spanish readers' perceptions of the literature and culture of their Antipodes. Since the range of authors and works I have mentioned is diverse, such codes differ widely: the emphasis on the biographies of canonical authors, the branding of authors as belonging to a world canon of the exotic or the indigenous, the capitalization on awarded prizes or successful film adaptations, and the preference that the translation market seems to have shown, on the one hand, for works by New Zealand authors which do not necessarily relate to a recognizable New Zealand setting and, on the other, for neo-colonial appropriations of New Zealand icons and culture to suit specific literary formulae.

By pointing at the coexistence of these very different marketing codes and editorial choices I hope to have offered a number of insights into how New Zealand is read in Spain. As a general conclusion, it could be added that none of these works are presented as belonging to a distinctive canon of "New Zealand or Pacific literature"; on the contrary, they simply come to integrate, as explained above, the canon of world writing available in Spanish. The appearance of further translations will expand these preliminary conclusions, hopefully allowing Spanish readers to fully wake up to the multitude of New Zealand and Pacific voices which remain untranslated. 
${ }^{1}$ Norman Franke, "While you were Sleeping," Waikato Times, 13 October, 2012,

http://www.stuff.co.nz/waikato-times/life-style/arts/7812113/While-you-were-sleeping, accessed 29 September, 2014.

${ }^{2}$ Ibid.

${ }^{3}$ Rafael Poch,"La literatura del fin del mundo se presenta en Frankfurt," La Vanguardia, 13 October, 2012, http://www.lavanguardia.com/libros/20121013/54353006934/literatura-fin-mundo-presentafrankfurt.html, accessed 29 September, 2014.

${ }^{4}$ El País, "Mientras usted está durmiendo," 9 October, 2012, http://cultura.elpais.com/cultura/2012/10/09/actualidad/1349780807 111724.html, accessed 29 September, 2014.

${ }^{5}$ In the case of Iceland, the emphasis was placed on the importance of its sagas and legendary traditions. See Carles Geli, "La Islandia literaria pugna contra la económica en Fráncfort," El País, 12 October, 2011, http://cultura.elpais.com/cultura/2011/10/12/actualidad/1318370404 850215.html, accessed 10 August, 2015, and Rosalía Sánchez, "Los vikingos toman Francfort," El Mundo, 11 October, 2011, http://www.elmundo.es/elmundo/2011/10/11/cultura/1318340175.html, accessed 10 August, 2015. Articles focusing on Finland drew attention to a relatively short literary history with which Spanish readers are, nevertheless, relatively familiar; see Winston Manrique Sanbogal, "Finlandia, el país que ama los libros", El País, 4 October, 2014, http://cultura.elpais.com/cultura/2014/10/02/babelia/1412266622_185872.html, accessed 10 August, 2015.

${ }^{6}$ The data for this article has been obtained from the ISBN database by the Spanish Ministry of Culture, http://www.mecd.gob.es/cultura-mecd/areas-cultura/libro/bases-de-datos-del-isbn/base-dedatos-de-libros.html, and the General Catalogue of the National Library,

http://catalogo.bne.es/uhtbin/webcat. I consider only the translations published and commercialized in Spain and in Spanish, excluding translations into Catalan, Basque or Galician.

${ }^{7}$ Sandra Ponzanesi, The Postcolonial Cultural Industry: Icons, Markets, Mythologies. (Basingstoke: Palgrave, 2014), 74.

${ }^{8}$ David Damrosch, What is World Literature? (Princeton: Princeton University Press, 2003), 4.

${ }^{9}$ Damrosch, What is World Literature?, 5.

${ }^{10}$ Gerry Kimber and Janka Kascakova, Katherine Mansfield and Continental Europe: Connections and Influences (Basingstoke: Palgrave, 2015).

${ }^{11}$ Gerry Kimber, Delia Da Sousa, and Janet Wilson, eds, Katherine Mansfield and the (Post)colonial. (Edinburgh: Edinburgh University Press, 2013).

${ }^{12}$ Janet Wilson, "Introduction," in Katherine Mansfield and the (Post)colonial, ed. Kimber et al., 3.

${ }^{13}$ Katherine Mansfield, El aloe (Sevilla: Barataria, 2012). This collection also includes the work of another New Zealander, C.K. Stead's Talking About O'Dwyer (1999) —Recordando a O'Dwyer (Sevilla: Barataria, 2004). C.K. Stead's My Name was Judas (2006) has also been translated as Mi nombre fue Judas (Barcelona: Grijalbo, 2007).

${ }^{14}$ Barataria, "Colecciones," http://www.barataria-ediciones.com/barbaros.html, accessed 30 September, 2014.

${ }^{15}$ Janet Wilson, "Introduction," 1.

${ }^{16}$ The focus on Mansfield's biography is not exclusive to the Spanish context. It has also been identified by Maurizio Ascari as influencing the early Italian translations of her work, in particular from the appearance of John Middleton Murry's edition of her letters and diaries. See Maurizio Ascari, "An 'Utterly Concrete and yet Impalpable' Art: The Early Reception of Katherine Mansfield in Italy (1922-1952)," in Katherine Mansfield and Continental Europe, 7-25.

${ }^{17}$ Katherine Mansfield, En la bahía (Madrid: Alba, 2001); En un balneario alemán (Madrid: Alba, 2011).

${ }^{18}$ Alba, "Katherine Mansfield,"

http://www.albaeditorial.es/php/sl.php?shop.searchFldrs\&nt=7455\&tqry=1\&ord=0\&sen=0\&cqry=16 8\&pagout=0\#.VClka1eE5K8, accessed 29 September, 2014. 
${ }^{19}$ Mansfield's diary for instance has been published by Ediciones del Cotal (1978), Ediciones B (1987), Parsifal (1994), Lumen (2008) and Debolsillo (2009).

${ }^{20}$ Claire Tomalin, Katherine Mansfield (Barcelona: Circe ediciones, 1992).

${ }^{21}$ Pietro Citati, La vida breve de Katherine Mansfield (Barcelona: Noguer, 1990).

${ }^{22}$ Gerry Kimber, Katherine Mansfield. The View from France (Bern: Peter Lang, 2008), 225.

${ }^{23}$ Janet Frame, Rostros en el agua (Madrid: Plaza y Janés, 1965).

${ }^{24}$ Janet Frame, Al Margen del Alfabeto (Madrid: Plaza y Janés, 1966).

${ }^{25}$ Michael King explains that rights were sold for the translation of Living in the Maniototo (1979) but I have been unable to locate any reference to this work. See King, Wrestling with the Angel. A Life of Janet Frame (London: Picador, 2000).

${ }^{26}$ Janet Frame, Rostros en el agua (Barcelona: Ediciones B, 1991).

${ }^{27}$ Janet Frame, Un ángel en mi mesa (Barcelona: Seix Barral, 1991).

${ }^{28}$ Janet Frame, Mona Minim y el olor del sol (Madrid: Siruela, 1994).

${ }^{29}$ Janet Frame, An Angel at My Table. An Autobiography (Auckland: Century Hutchitson, 1989), 387.

${ }^{30}$ Janet Frame, Hacia otro verano (Barcelona: Seix Barral, 2009).

${ }^{31}$ Patricia Grace, Potiki (Tafalla: Txalaparta, 1999).

${ }^{32}$ Alan Duff, Guerreros de antaño (Barcelona: Seix Barral, 1999).

${ }^{33}$ Witi Ihimaera, La leyenda de las ballenas (Barcelona: Editorial Juventud, 2004).

${ }^{34}$ Oliver Haag, "A History of Indigenous New Zealand Books in European Translation," Journal of New Zealand Studies 16 (2013): 85.

35 Ibid., 82.

${ }^{36}$ Andrew Mason, "Duff, Alan," in The Oxford Companion to New Zealand Literature, ed. Roger

Robinson and Nelson Wattie (Auckland: Oxford University Press), 150.

${ }^{37}$ Haag, "A History of Indigenous New Zealand Books," 89.

${ }^{38}$ Witi Ihimaera, The Whale Rider (New York: Harcourt, 2003).

${ }^{39}$ Graham Huggan, The Postcolonial Exotic: Marketing the Margins. (London: Routledge, 2001).

${ }^{40}$ Patrick Evans, The Long Forgetting. Post-Colonial Literary Culture in New Zealand

(Christchurch: anterbury University Press, 2007), 184.

${ }^{41}$ Editorial Juventud, La leyenda de las ballenas, http://www.editorialjuventud.es/3394.html, accessed 20 September, 2014.

${ }^{42}$ Haag, "A History of Indigenous New Zealand Books," 87.

${ }^{43}$ Jean Anderson, "Inside Out or Outside In? Translating Margins, Marginalizing Translations: The

Case of Francophone Pacific Writing,"TranscUlturAl 5, no. 2 (2013): 10.

${ }^{44}$ Ibid., 11.

45 "Declaration of Independence," in Declaración de independencia (Oviedo: KRK, 2011), and "Robocop in Long Bay" in Un país de cuento. Veinte Relatos de Nueva Zelanda, ed. Paloma FresnoCalleja and Janet Wilson (Zaragoza: Prensas de la Universidad de Zaragoza, 2014). This volume is the first anthology of New Zealand short stories published in Spanish and includes translations of short stories by Katherine Mansfield, Roderick Finlayson, Frank Sargeson, Dan Davin, Janet Frame, Maurice Shadbolt, Maurice Duggan, Joy Cowley, Witi Ihimaera, Maurice Gee, Patricia Grace, Keri Hulme, Vincent O’Sullivan, Fiona Kidman, Shonagh Koea, Owen Marshall, Barbara Anderson, Fiona Farrell and Sue Orr.

${ }^{46}$ Sia Figiel, L'indret d'on venim (Barcelona: La Magrana, 1999).

${ }^{47}$ Sia Figiel, El lugar donde nacimos (Barcelona: Seix Barral, 1999).

${ }^{48}$ Sia Figiel, La muchacha en el círculo de la luna (Tenerife: Baile del Sol, 2001). Some of the poems from her collection To a Young Artist in Contemplation (1998) were translated into Spanish and Catalan as a result of Figiel's participation at Aula de Poesía de Barcelona in 1999,

http://www.ub.edu/aulapoesiabarcelona/epublish/Sumari/A u d i t o r i/ Sia Figiel/ sia figiel.html, accessed 1 October, 2014. I have also translated Figiel's short story "The Dancers" for the Cuban journal Revolución y Cultura (2015).

${ }^{49}$ See, for instance, Inma Monsó, “¿Tristes tópicos?,” El País, 4 October, 1999, http://elpais.com/diario/1999/10/04/catalunya/938999241_850215.html, accessed 1 October, 2014, or Isabel Obiols, "Sia Figiel da voz a las mujeres de Samoa en 'L'indret d'on venim,"” El País, 10 
September, 1999, http://elpais.com/diario/1999/09/10/catalunya/936925656_850215.html, accessed 1 October, 2014.

${ }^{50}$ Ponzanesi, The Postcolonial Cultural Industry, 76.

${ }^{51}$ Merlinda Bobis, "'Voice-Niche-Brand': Marketing Asian-Australianness," Australian Humanities Review 45 (2008): 119-25.

${ }^{52}$ The novel Frangipani (2004) by Célestine Hitiura Vaite, a Tahitian author based in Australia who writes in English, has also been translated as Las hijas de Tahití (Madrid: Random House Mondadori, 2006); the title and cover design with a female figure wearing a red hibiscus in her ear exploits in a more evident way the exotic image of the Polynesian dusky maiden.

${ }^{53}$ Alison Wong, Cuando la tierra se vuelve de plata, (Madrid: Siruela, 2011).

${ }^{54}$ Alison Wong, "Writing Historical Fiction from a Cross-cultural Perspective. Seminar at Stout

Research Centre," 2003, http://www.victoria.ac.nz/stout-centre/about/events/events-pastseminars/publications/chinesenzawong.pdf, accessed 30 June, 2014.

${ }^{55}$ Elizabeth Knox, La suerte del viticultor (Barcelona: Seix Barral, 2011).

${ }^{56}$ Kirsty Gunn, Lluvia (Madrid: Anaya Muchnik, 1997); El recuerdo (Madrid: Alianza, 1999); Has vuelto a casa (Madrid: Alianza, 2000); Featherstone (Madrid: Alianza, 2005).

${ }^{57}$ Eleanor Catton, El ensayo general (Madrid: Siruela, 2003).

${ }^{58}$ Kate de Goldi, La pregunta de las diez de la noche (Madrid: Random House, 2011).

${ }^{59}$ Evans, The Long Forgetting, 181.

${ }^{60}$ Patrick Evans, "Spectacular Babies: the Globalisation of New Zealand Fiction," World Literature Written in English 38, no. 2 (2000): 94.

${ }^{61}$ Erin Mercer, "As Real as the Spice Girls: Representing Identity in Twenty-first Century New

Zealand Literature," Journal of New Zealand Studies 9 (2010): 102.

${ }^{62}$ Janet Wilson, "New Zealand Literary Nationalism and the Transcultural Future. Or: Will the Centre Hold?," in Towards a Transcultural Future. Literature and Society in a "Post"-Colonial World (ASNEL Papers 9.1; Cross Cultures 77), ed. Geoffrey Davis et al. (Amsterdam: Rodopi, 2004), 120. ${ }^{63}$ Ibid, 121.

${ }^{64}$ Evans, Spectacular Babies, 103.

${ }^{65}$ Kate Worthington, "Gunn, Kirsty," in The Oxford Companion to New Zealand Literature, ed. Robinson and Wattie, 221.

${ }^{66}$ Kirsty Gunn, "Place, Familiarity and Distance: What Katherine Mansfield Taught Me," Katherine Mansfield International Conference 2008, University of London, http://www.kirsty-gunn.com/writing, accessed 30 September, 2014.

${ }^{67}$ M. José Diaz de Tuesta, "Kirsty Gunn explora 'la intimidad aterradora' que crean las familias," $E l$ País, 30 June, 1999, http://elpais.com/diario/1999/06/30/cultura/930693603_850215.html, accessed 30 September, 2014. A similar argument could be used in relation to Barbara Ewing, a New Zealand writer and actress established in London, who talks of herself as having "two countries" (Barbara Ewing's Website, http://www.barbaraewing.com, accessed 10 September, 2014). Only two of her eight novels are partly set in New Zealand; the rest of her historical novels are set in various locations. As specified in her website, Ewing has been translated into many European languages (German, French, Italian, Swedish, Dutch, Greek, Turkish, Polish, Serbo-Croat, Russian and Portuguese) and five of her novels, mostly those that take place in European or North American settings, are also available in Spanish: Al otro lado del mundo (Barcelona: Suma de Letras, 2007), El circo fantasma (Madrid: Bóveda, 2008), Rosetta (Madrid: Bóveda 2010), El fraude (Madrid: La Factoría de Ideas, 2012), La hipnotizadora (Barcelona: Suma de Letras, 2012).

${ }^{68}$ Scottish Review of Books, "Interview: Kirsty Gunn," http://www.scottishreviewofbooks.org/index.php/back-issues/2013-03-27-15-25-26/volume-nineissue-three/563-srb-interview-kirsty-gunn, accessed 30 September, 2014.

${ }^{69}$ Kate de Goldi, "Simply by Sailing in a New Direction. The Search for Storyland," Griffith Review 43 (2014): 271.

${ }^{70}$ Ibid., 272. 
${ }^{71}$ Mahy received her education at Canterbury University College in Christchurch and lived in Governor's Bay. The Spanish translation of The Haunting (1982)—El aparecido (Madrid: Alfaguara, 1991) - locates Canterbury and the Governor's Bay area in England, rather than New Zealand.

${ }^{72}$ Sue Kedgley, Our Own Country. Leading New Zealand Women Writers Talk about their Writing and their Lives. (Auckland: Penguin, 1989); Kathryn Walls, "Mahy, Margaret," in The Oxford Companion to New Zealand Literature, ed. Robinson and Wattie, 329.

${ }^{73}$ Kedgley, Our Own Country, 142.

${ }^{74}$ Joy Cowley, Tere Tararea y las gafas (Madrid: Alfaguara, 2001); Tere Tararea hace piruetas (Madrid: Alfaguara, 2003).

${ }^{75}$ This claim could also be made for crime fiction set both inside and outside New Zealand. Ngaio Marsh's crime novels, most of which bear no connection to her country of birth, were published in Spanish from the 1940s to the 1980s. More recently, Paul Cleave's international bestseller Collecting Cooper: A Thriller (2011), set in Christchurch, appeared as El coleccionista (Barcelona: Grijabo, 2012).

${ }^{76}$ De Goldi, "Simply by Sailing in a New Direction," 272.

${ }^{77}$ Ponzanesi, The Postcolonial Cultural Industry, 2.

${ }^{78}$ Ibid., 3.

${ }^{79}$ Significantly, this process of adaptation can also work in reverse, turning successful films into novels, as in the case of Janet Campion's literary adaptations of her scripts for The Piano - co-written in 1993 with Kate Pulinger and published as El Piano (Madrid: Alfaguara, 1994) — and Holy Smoke, co-written in 1999 with Anna Campion, which appeared in Spanish with the same title (Madrid: Espasa, 2000).

${ }^{80}$ Eleanor Catton, Las luminarias, (Madrid: Siruela, 2014).

${ }^{81}$ Sarah Shieff, "the bone people: Contexts and Reception 1984-2004," in The Pain of Unbelonging: Alienation and Identity in Australasian Literature, ed. Sheila Collinwood-Whittick (Amsterdam: Rodopi, 2007), 143.

${ }^{82}$ Haag, "A History of Indigenous New Zealand Books," 90.

${ }^{83}$ Claire Squires, "Book Marketing and the Booker Prize," in Judging a Book by its Cover: Fans, Publishers, Designers, and the Marketing of Fiction, ed. Nicole Matthews and Nikianne Moody (London: Ashgate, 2007), 95.

${ }^{84}$ Ponzanesi, The Postcolonial Cultural Industry, 60.

${ }^{85}$ Ibid., 61.

${ }^{86}$ Richard Todd, Consuming Fictions: The Booker Prize and Fiction in Britain Today, (London: Bloomsbury, 1996); Huggan, The Postcolonial Exotic; Ponzanesi, The Postcolonial Cultural Industry. ${ }^{87}$ The first entry about the Booker Prize I could locate in El País, the most widely-read national newspaper, corresponds to 1986, the next to 1989; moving into the 1990s these very isolated references grow exponentially, with the most substantial increase evident from 2005. Since the mid2000 s, reviews and profiles of the Booker winners have become more frequent. "Premio Booker," http://elpais.com/tag/premio_booker, accessed 20 September, 2014.

${ }^{88}$ See, for instance, Pablo Guimón, "Todavía siento que no sé escribir una novela.” El País, 19 January, 2015, http://cultura.elpais.com/cultura/2015/01/18/actualidad/1421600971 070971.html, accessed 10 August, 2015; Inés Martín Rodrigo, "Eleanor Catton: 'Batir récords es cosa del deporte, no de la literatura." $A B C$, 29 January, 2015, http://www.abc.es/cultura/cultural/20150111/abcieleanor-catton-luminarias-201501091709.html, accessed 10 August, 2015.

${ }^{89}$ Lloyd Jones, El señor Pip (Barcelona: Salamandra, 2008).

${ }^{90}$ Lloyd Jones, El senyor Pip (Barcelona: RBA, 2008).

${ }^{91}$ Huggan, The Postcolonial Exotic.

${ }^{92}$ Sarah Lark, En el país de la nube blanca (Barcelona: Ediciones B, 2011); La canción de los maoríes (Barcelona: Ediciones B, 2012); El grito de la tierra (Barcelona: Ediciones B, 2012).

${ }^{93}$ The second trilogy is formed by Das Gold der Maori (2010), Im Schatten des Kauribaums (2011), Die Tränen der Maori-Göttin (2012), translated as Hacia los mares de libertad (Barcelona: Ediciones $\mathrm{B}, 2014)$ A la sombra del árbol kauri (Barcelona: Ediciones B, 2014), and Las lágrima de la diosa maorí (Barcelona: Ediciones B, 2015). There is a third saga formed by Die Zeit der Feuerblüten 
(2013), which has appeared as La estación de las flores en llamas (Barcelona: Ediciones B, 2015) and Der Klang des Muschelhorns (2013), which has not yet been published in Spain.

${ }^{94}$ Margot Molina, "Escribiría sobre el Cid Campeador, pero ¿a quién le interesa?," El País, 14 November, 2013, http://sociedad.elpais.com/sociedad/2013/11/14/actualidad/1384457028_885957.html, accessed 3 October, 2014.

${ }^{95}$ Another German author, also writing under a pseudonym, is Anne Laureen. Her novel Estrellas sobre Tauranga (Madrid: Maeva, 2012) was also inspired by the author's visit to New Zealand. ${ }^{96}$ La Voz de Almería, "Sarah Lark," 23 May, 2014, accessed 30 September, 2014.

${ }^{97}$ Antonio Abella, "La Nube Blanca Maorí", El Periódico, 19 September, 2011, http://www.elperiodico.com/es/noticias/ocio-y-cultura/nube-blanca-maori-996905, accessed 30 September, 2014; Álvaro Argote, "Los Hombres se Asustan al ver 800 páginas en un libro", El Mundo, 14 April, 2011, http://www.elmundo.es/elmundo/2011/04/14/cultura/1302800233.html, accessed 30 September, 2014; Alberto Piquero, “Todas mis novelas son optimistas", El Comercio 6 July, 2014, http://www.elcomercio.es/gente-estilo/201407/06/todas-novelas-optimistas20140706003844-v.html, accessed 30 September, 2014.

${ }^{98}$ Ponzanesi, The Postcolonial Cultural Industry, 77.

${ }^{99}$ Lark has also written a two-volume saga set in the Caribbean: Die Insel der tausend Quellen (2011) translated as La isla de las mil fuentes (Barcelona: Ediciones B, 2013) and Die Insel der roten Mangroven (2012) translated as Las olas del destino (Barcelona: Ediciones B, 2014).

${ }^{100} \mathrm{~A}$ similar case is discussed by Carter and Walker-Morrison in relation to Caryl Férey's crime novels which, in their view, also use the exotic in order to "disguise [the author's] outsider status and bolster the ethnographic credibility of these works by appropriating tropes from postcolonial literature and travellers' tales." See Ellen Carter and Deborah Walker-Morrison: "Cannibalistic Maori Behead Rupert Murdoch: (Mis) representations of Antipodean Otherness in Cary Férey's 'Maori Thrillers,", in The Foreign in International Crime Fiction: Transcultural Representations, ed. Jean Anderson, Carolina Miranda and Barbara Pezzotti (London: Continuum, 2012), 9-21; quotation from page 9. ${ }^{101}$ Ibid., 20. 